\title{
KODE ETIK KONSELING: TEORITIK DAN PRAKSIS
}

\author{
Aniswita $^{1}$, Neviyarni $^{2}$, Mudjiran $^{3} \&$ Herman Nirwana $^{4}$ \\ 1,2,3,4 Program Ilmu Pendidikan Universitas Negeri Padang \\ e-mail: ${ }^{1}$ aniswitaumar@gmail.com
}

\begin{abstract}
Abstrak
Perkembangan teknologi dan informasi membawa dampak yang sangat signifikan dalam semua dimensi kehidupan manusia. Mobilitas manusia semakin tinggi dan permasalahan menjadi semakin komplek. Saat seperti ini konseling menjadi sebuah kebutuhan, karena inti dari konseling adalah bantuan seorang ahli (konselor) yang diberikan kepada seseorang (konseli atau klien) untuk memecahkan masalahnya. Dalam memberikan pelayanan tersebut seorang konselor diatur oleh kode etik yang menjadi dasar bagi konselor untuk bersikap. Kode etik konselor ditetapkan oleh lembaga profesi konselor. Untuk konteks Indonesia kode etik konselor ditetapkan oleh Asosiasi Bimbingan Konseling Indonesia, yang disingkat dengan ABKIN. Kode etik merupakan panduan atau pedoman tingkah laku profesional atau sebagai landasan moral yang diamalkan, diamankan dan dijunjung tinggi oleh konselor sebagai anggota organisasi profesi. Kode etik ini penting dijadikan sebagai panduan karena merupakan seperangkat aturan yang dapat melindungi profesi konselor dari intervensi pemerintah, mencegah permasalahan internal, dan membentengi konselor dari perilaku malpraktik serta meningkatkan kepercayaan publik terhadap profesi konselor. Secara teoritik kode etik harus dilaksanakan dan mengikat konselor dalam memberikan pelayanan, tetapi ada kondisi di lapangan yang dilematis yang membuat konselor sulit untuk menegakkan kode etik. Berdasarkan hal tersebut, penulis tertarik untuk membahas kode etik konselor dalam kajian teoritik dan praksis.
\end{abstract}

Kata Kunci: Kode etik Konseling, Kajian teoritik, Praksis

\begin{abstract}
The development of technology and information has a very significant impact in all dimensions of human life. Human mobility is getting higher and problems are becoming more complex. At times like this, counseling becomes a necessity, because the essence of counseling is a helping of an expert (counselor) who is given to someone (counselee or client) to solve the problem. In providing these services a counselor is governed by a code of ethics which forms the basis for the counselor to behave. The counselor's code of ethics is set by the counselor professional institution. For the Indonesian context, the counselor's code of ethics is set by the Indonesian Counseling Guidance Association, which is abbreviated as ABKIN. A code of ethics is a guide or guidelines for professional behavior or as a moral foundation that is practiced, safeguarded and upheld by the counselor as a member of professional organizations. This code of ethics is important as a guide because it is a set of rules that can protect the counselor profession from government intervention, prevent internal problems, and fortify counselors from malpractice behavior and increase public trust in the counselor profession. Theoretically, a code of ethics must be implemented and bind the counselor in providing services, but there are dilemma on the ground that make it
\end{abstract}


difficult for counselors to enforce the code of ethics. Based on this, the author is interested in discussing the counselor's code of ethics in theoretical and practical studies.

Keywords: Counseling Code of Ethics, Theoretical Studies, Praxis

\section{PENDAHULUAN}

Abad 21 disebut juga dengan era revolusi industri 4.0 atau era digital. Era ini ditandai dengan perkembangan teknologi informasi yang sangat signifikan. Perkembangan ini membawa dampak terhadap seluruh aspek kehidupan manusia. Mobilitas manusia menjadi sangat tinggi dan permasalahan hidup juga menjadi semakin kompleks. Hal ini menjadikan konseling sebagai suatu kebutuhan. John Mcleod (2003) mengatakan bahwa Counselling is a really useful option at these moments.

Konseling diartikan sebagai upaya memberikan bantuan yang diberikan oleh seorang professional kepada orang lain untuk bersama sama memecahkan masalah mereka. Sesuai dengan pendapat Burks and Stefflre dalam Mcleod (2003), konseling sebagai hubungan professional antara konselor dengan klien, untuk membantu mereka menentukan tujuan hidup supaya lebih bermakna. Diperkuat oleh Soesmayah (1981) yang mengartikan konseling sebagai suatu situasi pemecahan masalah, dimana individu memusatkan perhatiannya dengan bantuan ahli atau pakar yang dipercaya untuk memecahkan masalah dalam suasana tenang, bebas, bersifat terbuka dan face to face atau tatap muka. Jadi penekanan dari makna konseling adalah bantuan dari profesional (konselor) kepada konseli sehingga bersama sama memecahkan masalahnya.

Dari definisi tersebut terlihat tujuan konseling dalam jangka pendek adalah membantu konseli (klien) dalam menyelesaikan masalahnya. Sedangkan tujuan jangka panjangnya klien mampu menyelesaikan masalahnya sendiri tampa bantuan orang lain. Bantuan ini biasanya diberikan dalam bentuk layanan. Untuk memberikan layanan yang efektif, konselor dituntut untuk bersikap professional. Sikap professional inilah yang disebut dengan kode etik. Seperti profesi lainnya, konselor juga memiliki kode etik yang sudah diatur oleh organisasi profesi konselor. Untuk Indonesia organisasi profesi konselor disebut Asosiasi Bimbingan Konseling Indonesia disingkat dengan ABKIN yang menaungi dan mengawasi konselor dalam memberikan layanan termasuk penegakkan kode etik konselor.

Pada tataran implementasi (praksis), terdapat beberapa situasi dilematis yang rentan berpengaruh terhadap konselor untuk bersikap. Saat ini lah dibutuhkan kode etik yang diperluas dan standar tingkah laku yang dilandasi nilainilai yang telah disetujui bersama antara konselor dan konseli (Hansen dalam Gladding, 2012). Selain itu, terjadi juga beberapa pelanggaran kode etik di lapangan oleh oknum konselor seperti membocorkan rahasia konseli, adanya pemaksaan cara berfikir, pelecehan dan lainnya. Berikut dibahas tentang kode etik konseling dalam kajian teoritik dan praksis.

\section{METODOLOGI}

Metode penelitian yang digunakan adalah studi literatur atau kajian pustaka. Peneliti mengkaji bahan-bahan pustaka yang terkait dengan pembahasan yaitu tentang kode etik dalam teori dan praksis. Sesuai dengan pendapat Zed 
(2014), Penelitian kajian pustaka adalah serangkaian kegiatan yang berkaitan dengan metode pengumpulan data pustaka, membaca dan mencatat, serta mengolah data penelitian.

\section{HASIL PENELITIAN DAN PEMBAHASAN Etika Konselor}

Secara etimologi atau asal kata, padanan kata "etika" adalah "ethics" (dalam bahasa Inggris), memiliki arti ilmu tentang moral, akhlak, tingkah laku dan kesusilaan. Sedangkan menurut Kamus Besar Bahasa Indonesia (KBBI) etika adalah, ilmu tentang sesuatu yang baik atau buruk serta tentang hak dan kewajiban moral (akhlaq). Menurut Van Hoose \& Kottler (1985) dalam Gladding (2012), etika (ethics) merupakan ilmu filsafat tentang tingkah laku manusia. Jadi, dapat disimpulkan bahwa etika adalah sebuah ilmu tentang moral dan tingkah laku manusia.

Etika merupakan sesuatu yang penting dalam konseling, seperti yang dikatakan oleh Franz Mgnis-Suseno (1987) yaitu: 1) Tidak adanya kesatuan tatanan normatif, sehingga etika menjadi salah satu acuan yang dapat digunakan dalam memberi pelayanan; 2) Etika diperlukan untuk memberi bekal ketika terjadi transformasi di bidang ekonomi, sosial, intelektual dan budaya tradisional ke modern; 3) Etika menjadikan seseorang kritis dan objektif serta mampu memberi penilaian terhadap ideologi baru. Secara umum dapat dikatakan bahwa etika menjadi acuan moral bagi konselor dalam memberikan layanan.

\section{Kepribadian dan Etika Konselor}

Kepribadian atau perilaku konselor merupakan unsur terpenting dalam pemberian layanan. Holik (2016) mengatakan bahwa pengetahuan dan keterampilan dalam konseling saja tidak cukup dalam memberikan bantuan tampa didukung oleh kepribadian konselor. Hal ini karena dalam layanan, pengetahuan, keterampilan, pengalaman dan kualitas kepribadian konselor sangat berpengaruh terhadap efektivitas layanan. Sikap atau perilaku yang harus dimiliki oleh konselor diantaranya adalah sebagai berikut: 1) Menciptakan hubungan dan suasana yang kondusif dalam memberikan layanan; (2) Bersikap objektif terhadap konseli; (3) Menggali faktor penyebab masalah psikologis konseli; (4) Menentukan kerangka referensi atau perangkat kognitif yang dapat dipahami konseli untuk memecahkan masalahnya; (5) Konselor harus memiliki strategi untuk mengubah keyakinan konseli yang tidak rasional atau gangguan emosi yang menyalahkan diri sendiri; (6) Memberikan pemahaman tentang perilaku baru yang diperlukan konseli dalam kehidupan kesehariannya; (7) Menjadi contoh atau model yang memiliki sikap atau perilaku sehat dan normal; (8) Menyadari kesalahan yang pernah dilakukan serta resiko yang dihadapi; (9) Mampu menjaga kerahasiaan dan dapat dipercaya; (10) Memiliki orientasi diri yang dinamis dan selalu berkembang; dan (11) Ikhlas dalam menjalankan profesinya (Suherman dalam Eko Sujadi, 2018). Konselor yang profesional adalah konselor yang memiliki kepribadian yang baik, sehat dan mantap, yang diperlukan dalam memberikan bantuan atau layanan. Tidak mungkin seorang konselor dapat membantu konseli memecahkan masalahnya, jika konselor sendiri memiliki kepribadian yang rapuh. 
Selain itu, Maftu Holik (2016) juga menjelaskan etika yang harus di miliki seorang konselor yaitu: 1) Menghormati konseli sebagai individu yang memiliki potensi untuk dapat menghadapi permasalahannya; 2) Menjaga kerahasiaan permasalahan konseli, identitas maupun data; 3) Memberikan layanan konseling dalam ruang lingkup kualifikasi professional; 4) Memberikan bantuan yang disesuaikan dengan kemampuan; 5) Mengalihtangankan konseli kepada pihak lain jika kebutuhan konseli di luar batas kesanggupannya; 6) Meningkatkan profesionalitas secara umum melalui workshop, penelitian, dan pengembangan diri lainnya dalam bidang terkait; 7) Meningkatkan profesionalitas secara khusus sesuai dengan kebutuhan konseli; 8) Menjalin kemitraan atau kerjasama dengan berbagai pihak yang terkait dalam rangka pemberian layanan optimal kepada konseli; 9) Mengevaluasi kemampuan dan kinerja secara berkala sebagai bahan dalam rangka pengembangan diri; 10) Menghindari memanfaatkan konseli untuk kepentingan pribadi.

\section{Kode Etik Konselor}

Penekanan etika yaitu pada ilmu tentang nilai dan moral, jadi sifatnya lebih umum. Sedangkan kode etik sifatnya lebih khusus yaitu merupakan seperangkat norma atau aturan susila, nilai, moral, sikap atau akhlak yang disepakati dan ditaati bersama oleh setiap anggota dalam suatu organisasi. Hampir sama dengan pendapat Sunaryo Kartadinata (2011) yang mengatakan bahwa kode etik profesi merupakan regulasi atau norma perilaku profesional yang harus ditaati oleh setiap anggota profesi dalam baik dalam menjalankan tugas keprofesiannya atau dalam kehidupannya di masyarakat. Jadi kode etik melekat pada sebuah organisasi yang mengatur anggota organisasi profesi tersebut dalam pelaksanaan tugas dan dalam kehidupannya di tengah-tengah masyarakat.

Konselor merupakan profesi yang memiliki seperangkat aturan, norma dan nilai yang harus diindahkan dan ditaati bersama oleh seluruh anggota profesi. Untuk konteks Indonesia, Yusuf (2010) mengatakan bahwa kode etik konselor adalah landasan moral dan pedoman tingkah laku profesional yang harus dijunjung tinggi dan dilaksanakan oleh setiap anggota profesi bimbingan konseling di Indonesia. Aturan ini berlaku untuk seluruh anggota profesi bimbingan konseling di Indonesia untuk seluruh tingkatan dan daerah. Ditegaskan oleh ABKIN (2018) kode etik konselor merupakan seperangkat norma, sistem nilai dan moral yang mendasari perilaku anggota profesi dalam menjalankan tugas keprofesiannya dan kehidupan di masyarakat dalam rangkaian budaya tertentu.

Tujuan disusunnya kode etik konseling Indonesia yaitu: 1) Memberikan panduan sikap atau perilaku yang berkarakter dan profesional bagi anggota dalam memberikan layanan; 2) Membantu dalam memberikan pelayanan yang profesional; 3) Mendukung visi dan misi organisasi profesi; 4) Menjadi landasan dalam menyelesaikan masalah yang datang dari anggota profesi; 5) Melindungi konselor dari konseli (PBABKIN, 2018). Kode etik konselor juga bisa meningkatkan akuntabilitas dan integritas organisasi profesi konselor (Juhnke, dan Nielsen dalam Masruri (2016)) dan pelaksanaan pelayanan konseling menjadi lebih efektif.

Kode etik profesi bimbingan konseling Indonesia disusun oleh ABKIN dan dituangkan dalam SK no: 009/SK/PBABKIN/VIII/2018. Kode etik tersebut memuat hal sebagai berikut: 1) Kualifikasi dan kompetensi konselor yang 
mencakup; a) nilai, sikap, keterampilan, pengetahuan dan wawasan dalam bidang bimbingan konseling, b) adanya pengakuan atau legitimasi kemampuan dan kewenanganya sebagai konselor; 2) Kegiatan profesional yang mencakup; a) praktek pelayanan konseling secara umum, b) praktek pada unit atau lembaga, c) praktek mandiri, d) dukungan teman sejawat, e) informasi dan riset, f) assesmen atau penilaian; 3) Pelaksanaan pelayanan memuat; a) penghargaan dan keterbukaan, b) kerahasiaan dan berbagi informasi, c) setting layanan konseling, d) tanggung jawab konselor; 4) Pelanggaran dan sanksi memuat; a) bentuk pelanggaran, b) sanksi pelanggaran, c) mekanisme penerapan sanksi.

\section{Permasalahan Praksis Kode Etik Konselor}

Kode etik konselor dalam tataran praksis masih menyisakan banyak masalah. Penelitian yang dilakukan oleh Suhertina (2010) terkait dengan implementasi kode etik bimbingan konseling. Penelitian tersebut mengungkapkan bahwa Guru bimbingan konseling atau konselor sekolah masih banyak memiliki pemahaman yang relatif rendah terkait dengan kode etik profesi. Temuan yang sangat mengejutkan yakni sebagian konselor sekolah tidak mengenal adanya kode etik bimbingan konseling (Sujadi, 2018). Hal ini terjadi karena kesalahpahaman tentang bimbingan konseling khususnya bimbingan konseling di sekolah (Prayitno \& Erman Amti, 2004).

Secara garis besar permasalahan kode etik dapat dibagi dua, yaitu:

1. Pelanggaran Kode Etik

Menurut Hunainah (2016); Nuzliah (2019) minimal terdapat tiga kasus pelanggaran kode etik yang sering terjadi dalam pelaksanaan layananan koseling diantaranya adalah: 1) Pelanggaran yang dilakukan terhadap konseli. Contohnya, membuka rahasia konseli, melakukan perbuatan asusila dan melakukan tindak kekerasan atau kesalahan dalam memberikan layanan; 2) Pelanggaran terhadap organisasi profesi. Contohnya tidak melaksanakan aturan yang telah ditetapkan dan mencemarkan nama baik organisasi profesi; 3) Pelanggaran terhadap rekan sejawat atau profesi lain yang terkait. Contohnya tindakan yang tidak menyenangkan.

Isu pelanggaran kode etik paling mutahir dikemukakan Gladding yaitu: 1) Pelanggaran terkait kepercayaan; 2) Layanan yang diberikan melampaui tingkat kompetensi profesional; 3) Konselor melakukan kelalaian dalam memberikan layanan; 4) Konselor mengklaim kompetensi yang tidak dimilikinya; 5) Konselor memaksakan referensi, nilai atau prinsip pada konseli; 6) Konselor membuat konseli tergantung dan tidak mandiri; 7) Melakukan aktivitas asusila atau pelecehan terhadap konseli; 8) Adanya konflik kepentingan, seperti konselor berperan ganda yaitu sebagai konselor sekaligus peran lain baik dalam hubungan pribadi ataupun hubungan profesional; 9) Adanya kesepatan yang kurang jelas seperti masalah finansial atau adanya bayaran tambahan; 10) Adanya pengiklanan yang tidak pada tempatnya; 11) Plagiasi.

Pelanggaran kode etik ini umumnya terjadi disebabkan oleh: 1) Tidak adanya mekanisme atau prosedur yang jelas untuk menyampaikan keluhan terkait pelanggaran kode etik. Hal ini mengakibatkan kontrol atau pengawasan dari masyarakat tidak berjalan dengan baik; 2) Pengetahuan masyarakat yang minim tentang substansi kode etik profesi konselor; 3) Belum adanya 
kesadaran etis dari konselor untuk menjaga harkat dan martabat profesinya; 4) Adanya hubungan kekerabatan antara pelanggar kode etik dengan pihak yang berwenang menegakkan kode etik; 5) Lemahnya penegakan hukum di Indonesia sehingga pelaku pelanggaran kode etik profesi tidak bisa dijerat hukum (Hunainah, 2016). Jadi secara umum semua terjadi karena kurangnya tanggung jawab profesional dari pelanggar kode etik (oknum konselor).

2. Dilema legal dan etik dalam konseling

Permasalahan praksis kode etik selain pelanggaran kode etik adalah adanya dilema legal dan etik dalam konseling yang membuat konselor kesulitan atau dilematis untuk menegakkan kode etik profesi konselor. Tim Bond menjelaskan beberapa bentuk dilema etik dalam bimbingan konseling, diantaranya adalah: 1) Adanya kemampuan dan pengawasan serta kepercayaan yang harus dijaga oleh konselor (power, control and trust); 2) Adanya kesepakatan (contracting) antara pihak konselor dengan konseli; (3) Kerahasiaan data konseli yang harus dijaga (confidentiality); (4) Adanya kasus konseli berniat untuk bunuh diri (suicidal intent); dan (5) Adanya bahaya atau ancaman terhadap orang lain (danger to others).

\section{KESIMPULAN DAN SARAN}

Berdasarkan pembahasan kode etik konselor di atas, dapat ditarik kesimpulan sebagai berikut:

1. Secara teoritis, dalam memberikan layanan, konselor diikat oleh kode etik yang dijadikan sebagai pedoman moral atau sikap. Kode etik profesi konselor disusun dan diawasi oleh organisasi profesi di Indonesia oleh ABKIN yang melekat untuk setiap anggota organisasi tersebut. Tujuan disusunya kode etik konselor adalah sebagai panduan perilaku, membantu dalam mengembangkan layanan, mendukung misi organisasi profesi, sebagai landasan menyelesaikan masalah konselor dan melindungi konselor dari konseli.

2. Secara praksis masih banyak terdapat pelanggaran kode etik yang dilakukan oleh oknum konselor karena kurangnya tanggung jawab profesional. Minimal tiga jenis pelanggararan dilakukan yaitu: pelanggaran terhadap konseli, organisasi profesi dan rekan sejawat atau lembaga profesi lain. Selain itu juga terdapat beberapa kondisi dilematis yang menyebabkan konselor sulit untuk menegakkan kode etik konselor.

Dari pembahasan dan kesimpulan yang diperoleh, dapat diberikan beberapa saran sebagai berikut.

1. Memperkuat organisasi profesi sehingga mampu menegakkan kode etik profesi

2. Menyiapkan regulasi dan peraturan untuk memperkuat penegakkan kode etik konselor

3. Peningkatan kapasitas konselor sehingga mampu memahami dan menegakkan kode etik dalam memberikan layanan konseling.

4. Mengedukasi masyarakat pentingnya konseling untuk membantu menyelesaikan masalah mereka dan dalam pelaksanaan layanan, konselor diikat oleh kode etik. 


\section{DAFTAR PUSTAKA}

Eko Sujadi. (2018). Kode Etik Profesi Konseling Serta Permasalahan Dalam Penerapannya. Tarbawi: Jurnal ilmu pendidikan, vol 14 (2), hal 69-77

Franz Mgnis-Suseno. (1987). Etika Dasar Masalah-masalah Pokok Filsafat Moral. Yogyakarta: Kanisius.

Gladding. (2012). Counseling: a Comprehensive Profession, alih bahasa: Winarno \& Lilian Yuwono, Jakarta: PT. Indeks,

Hunainah. (2016). Etika Profesi Bimbingan Konseling. Bandung: Risqi Press

John Mcleod. (2003). An Introduction to Counselling. Great Britain: Bell \& Bain Ltd., Glasgow

Kamus Besar Bahasa Indonesia (KBBI). https://kbbi.web.id

Maftu Holik. (2016). Review buku: Ethical Reasoing In The Mental Health Profesions. Insight: Jurnal bimbingan konseling, Vol 5 (2), hal 204-2015.

Masruri. (2016). Etika Konseling Dalam Kontek Lintas Budaya dan Agama. AlTazkiah, vol 5 (2), hal 139-150.

Mestika Zed. (2014). Metode Penelitian Kepustakaan. Jakarta: Yayasan Pustaka Obor Indonesia

Nuzliah \& Irman Siswanto. (2019). Standarisasi Kode Etik Profesi Bimbingan Dan Konseling. Edukasi: Bimbingan dan Konseling, Vol 5 (1), hal 64-75.

Ondi Saondi \& Aris Suherman (2010). Etika Profesi Keguruan. Bandung Refika Aditama

Prayitno \& Amti, Erman. (2004). Dasar-dasar Bimbingan dan Konseling. Jakarta: PT Rineka Cipta.

SK no 009/SK/PBABKIN/VIII/2018. (2018). Kode Etik Bimbingan dan Konseling Indonesia. Jakarta: PBABKIN

Syamsu Yusuf. (2010). Landasan Bimbingan dan Konseling. Bandung: Remaja Rosda Karya.

Soesmayah. (1981). Pengertian Bmbingan dan Perananya dalam Pembimbingan Mahasiswa. Jakarta: Depdikbud

Sunaryo Kardinata. (2011). Menguak Tabir Bimbingan dan Konselor Sebagai Upaya Pedagogis. Bandung: UPI Press

Tim Bond. (2000). Handbook of Counselling ang Psychotherapy, edited by Colin Feltman and Lan Horton, London : Sage Publications. h : 235-241. 